\title{
Litterfall, litter layer and leaf decomposition in Eucalyptus stands on Cerrado soils
}

\author{
Produção, acúmulo de serapilheira e decomposição foliar em \\ povoamento de eucalipto sobre solo do Cerrado
}

\author{
Marco Bruno Xavier Valadão ${ }^{*}$, Karla Monique Silva Carneiro ${ }^{2}$, Jonas Inkotte ${ }^{1}$, \\ Fabiana Piontekowski Ribeiro ${ }^{1}$, Eder Pereira Miguel $^{1}$ e Alcides Gatto ${ }^{1}$
}

\begin{abstract}
The success of Eucalypt cultivation in Brazil was the result of decades of research, improvement of cultivation technologies, along with favorable edaphoclimatic properties. Nowadays, Eucalypt plantations are the main source of wood in the country. However, there are persisting doubts about the impacts on hydric, chemical and biological patters on the soil by this monoculture forest. For this reason, the understanding of the nutrient biogeochemical cycle linked to the litter dynamics contributes to elucidate the changes occurring in the physicochemical and biological properties of the soil. Thus, this work evaluated litterfall, litter layer and leaf decomposition in Eucalypt plantation 60 months-age in the Cerrado area, Distrito Federal. 360 days after experiment initiation, the remaining mass of leaves corresponded to $68.72 \%$, indicating a highly recalcitrant litter. It was concluded that there is an intense production and accumulation of plant material, which undergoes decomposition at a slow rate. This longer time of permanence of litter on the ground provides a favorable niche for edaphic fauna, protecting the superficial layer of the soil by reducing the impact of the kinetic energy of raindrops and allowing for improvement in water infiltration and, consequently, maintenance of the soil hydric capacity.
\end{abstract}

Keywords: remaining biomass, litter bags, $k$ decomposition constant, dystrophic soil.

\section{RESUMO}

O êxito da eucaliptocultura no Brasil foi resultado de décadas de pesquisa, aprimoramento de tecnologias de cultivo, aliado às propriedades edafoclimáticas favoráveis. Atualmente, os plantios dessa espécie são a principal fonte de madeira no país. Entretanto, dúvidas a respeito de impactos nos padrões hídricos, químicos e biológicos do solo, advindos dessa monocultura florestal ainda carecem de elucidações. Por esta razão, o entendimento do ciclo biogeoquímico de nutrientes ligado à dinâmica da serapilheira contribui para elucidar as modificações que ocorrem nas propriedades físico-químicas e biológicas do solo. Assim, este trabalho avaliou a produção, acúmulo e decomposição de serapilheira em plantio eucalipto aos 60 meses de idade em área de Cerrado no Distrito Federal. Aos 360 dias após o início do experimento, a porcentagem de massa remanescente correspondia a $68,72 \%$ indicando uma serapilheira altamente recalcitrante. Conclui-se que há uma intensa produção e acúmulo de material vegetal, porém com uma lenta decomposição. Esse maior tempo de residência da serapilheira proporciona um nicho favorável à fauna edáfica e proteção da camada superficial do solo, por meio da redução do impacto da energia cinética das gotas de chuva, possibilitando assim, uma melhora na infiltração de água e consequentemente manutenção da capacidade hídrica no solo.

Palavras-chave: biomassa remanescente, sacolas de decomposição, constante $k$ de decomposição, solo distrófico.

\section{INTRODUCTION}

Litterfall is the main input form of carbon and nutrients to the soil; where they are important components of the biogeochemical cycle. In a Eucalypt stand, the material coming from the litter guarantees the return of nutrients to the soil (VIERA et al., 2014a), mainly due to the large amount of plant material deposited on the ground (GIÁCOMO et al., 2017). In addition, plant residues

\footnotetext{
1. Forestry Department, Universidade de Brasília - UnB. Brasília / DF, Brazil. * Corresponding author: marcobrunovaladao@gmail.com
} 2. Ecology and Conservation Department, Universidade do Estado do Mato Grosso - UNEMAT. Nova Xavantina / MT, Brazil. 
decompose to the formation of organic matter, which releases $\mathrm{P}, \mathrm{Fe}, \mathrm{Mn}, \mathrm{Zn}$ and $\mathrm{K}$ as it is mineralized (VIERA et al., 2014b). In general, the balance of macronutrients in the soil-plant system is also positive in plantations conducted in dystrophic soils of the Brazilian Cerrado (GATTO et al., 2014).

In wetlands, production and decomposition of organic material occurs at a fast pace and consequently, there is a greater return of nutrients. In contrast, due to the edaphoclimatic conditions, production and decomposition of organic matter in the Cerrado tend to be slower, so much more in the case of Eucalypt plantations due to the high lignin present in the litterfall (COSTA et al., 2005). However, Eucalypt stands present good soil-water retention capacity (SUZUKI et al., 2014) and satisfactorily maintain soil physical properties (ASSIS et al., 2015).

Inquiries regarding impacts of plantations on large areas are often discussed (FARINACI et al., 2013). Such questions are completely valid and pertinent; nevertheless, it is for the scientific and the academic community to demonstrate the sustainability of Eucalypt culture in Brazil. Thus, this study aimed to evaluate litterfall, litter layer and leaf decomposition in Eucalypt stand in the Cerrado. The work also tested different periods of litter bags rescue in order to ascertain differences of the parameters obtained through the exponential regression.

\section{MATERIAL AND METHODS}

\section{Study area and sample design}

The work was conducted in the Água Limpa Farm, which belongs to the University of Brasília, situated in the Distrito Federal ( $15^{\circ} 56^{\prime}-1559^{\prime} \mathrm{S}$ and $47^{\circ} 55^{\prime}-4758^{\prime} \mathrm{WGr}$.). The property occupies a total area of $4,340 \mathrm{ha}$, about 2,340 ha of which are intended for preservation, while 1,200 ha are for academic studies focused on wood production, livestock and agriculture.

The climate in the region is described by Köppen as AW, with maximum and minimum temperatures of $28.5{ }^{\circ} \mathrm{C}$ and $12.0{ }^{\circ} \mathrm{C}$, respectively (ALVAREZ et al., 2014). During the collection period, from November 2015 to October 2016, average temperature was $21.0^{\circ} \mathrm{C}$; total precipitation was 1,115 mm, information made available by the Água Limpa Farm automatic climatological station (Figure 1). Soils within the study area are described as dystrophic Red Latosol (Oxisol).

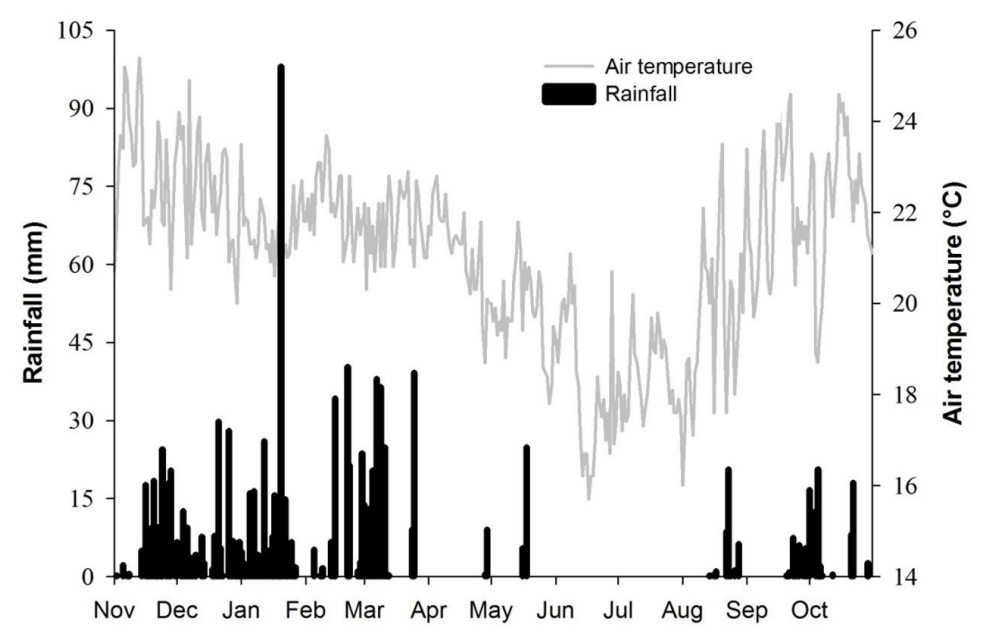

Figure 1. Rainfall (mm) and air temperature ( $\left.{ }^{\circ} \mathrm{C}\right)$ from November 2015 to October 2016 at Fazenda Água Limpa, Universidade de Brasília, Distrito Federal.

Figura 1. Precipitação $(\mathrm{mm})$ e temperatura do ar $\left({ }^{\circ} \mathrm{C}\right)$ de novembro de 2015 a outubro de 2016 na Fazenda Água Limpa, Universidade de Brasília, Distrito Federal.

The low base saturation $(\mathrm{V}<50 \%)$ and high aluminum saturation $(\mathrm{m})$ make these soils dystrophic (SOUSA; LOBATO, 2004). The low $\mathrm{Ca}^{2+}+\mathrm{Mg}^{2+}$ contents (Table 1) reflected the acidic nature of the soil. In this condition, the microbial activity is very limited, mainly bacterial (LAUBER et al., 2009), which results in low mineralization rates of organic matter (MIRANDA et al., 2007).

The stand selected for conducting the study comprises a total area of 3.29 ha and was established in January 2010 (60 months). The planting of I224 clone Eucalyptus urophylla S. T. Blake x Eucalyptus grandis Hill ex-Maiden was performed in a $3 \mathrm{~m} \mathrm{x} 2 \mathrm{~m}$ spacing. Preparation of the soil was done by plowing down to $40 \mathrm{~cm}$ depth. Fertilization was practiced along the planting line by application of 
Valadão et al. - Litterfall, litter layer and leaf decomposition in Eucalyptus stands on Cerrado soils

Table 1. Chemical attributes of a dystrophic Red Latosol under a Eucalypt stand at Água Limpa Farm, Distrito Federal*. Tabela 1. Atributos químicos de um Latossolo Vermelho distrófico sob povoamento de eucalipto, na Fazenda Água Limpa, Distrito Federal*.

\begin{tabular}{|c|c|c|c|c|c|c|c|c|c|c|c|c|c|}
\hline \multirow{2}{*}{ Depth (cm) } & $\mathrm{pH}$ & $\mathbf{P}$ & $\mathbf{K}^{+}$ & $\mathrm{OC}^{(1)}$ & $\underline{\mathrm{H}+\mathrm{Al}}$ & $\mathrm{Al}^{3+}$ & $\mathrm{Ca}^{2+}+\mathrm{Mg}^{2+}$ & $\mathbf{S}^{(2)}$ & $\mathrm{CEC}_{\mathrm{t}}^{(3)}$ & $\mathrm{CEC}_{\mathrm{T}}^{(4)}$ & \multirow{2}{*}{$\frac{\mathrm{OM}^{(5)}}{{\text { dag } \mathrm{Kg}^{-1}}^{-1}}$} & $\mathbf{B S}^{(6)}$ & $\mathrm{m}^{(7)}$ \\
\hline & $\mathrm{H}_{2} \mathrm{O}$ & \multicolumn{2}{|c|}{$\mathrm{mg} \mathrm{dm}^{-3}$} & $\mathrm{mg} \mathrm{g}^{-1}$ & \multicolumn{6}{|c|}{ 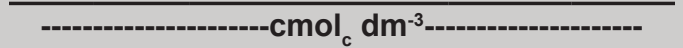 } & & \multicolumn{2}{|c|}{-----\%---- } \\
\hline & 4.9 & 2.6 & 12.9 & 26.0 & 8.9 & 0.70 & 0.39 & 0.4 & 1 & 9.3 & 4.5 & 4.6 & 60.5 \\
\hline & 5.1 & 1.4 & 14.7 & 20.5 & 20.5 & 0.26 & 0.36 & 0.4 & 1 & 7.6 & 3.5 & 4.7 & 42.3 \\
\hline $40-60$ & 5.5 & 1.7 & 16.2 & 4.10 & 5.1 & 0.04 & 0.43 & 0.5 & 1 & 5.6 & 0.7 & 8.6 & 6.8 \\
\hline
\end{tabular}

(1)Organic carbon; ( ${ }^{(2)}$ Sum of bases; ${ }^{(3)}$ Cation exchange capacity (effective); ${ }^{(4)}$ Cation exchange capacity (total); (5)Oganic Matter; ${ }^{\left({ }^{(6)} B a s e ~ s a t u r a t i o n ; ~\right.}$ (7)Aluminum saturation index. *Data collected: March 2016.

$100 \mathrm{~g}$ of super simple phosphate $+100 \mathrm{~g}$ of NPK (4-30-16); liming was not performed previously. A total of 40 plots, $10 \mathrm{~m} \mathrm{x} 10 \mathrm{~m}$ plots were randomly marked for monthly monitoring of litterfall, litter layer and leaf decomposition along 12 months.

\section{Litterfall}

Forty litter traps $(0.50 \mathrm{~m} \times 0.50 \mathrm{~m})$ were distributed along the centerline of each plot to quantify litterfall. The area sampled was within the recommended limit for litterfall samplings, which considers a minimum of eight litterfall traps per hectare (FINOTTI et al., 2003).

Monthly collections were performed between November 2015 and October 2016. Samples were divided into fractions to separate leaves, reproductive parts, branches and miscellaneous residues. Litterfall was quantified by means of constant dry weight after oven drying at $65^{\circ} \mathrm{C}$ and weighing of the fractions on a precision scale.

\section{Litter layer}

The litter layer was evaluated through monthly collections from November 2015 to October 2016. In order to do the evaluation, a $0.50 \mathrm{~m} \times 0.50 \mathrm{~m}$ metal template was randomly cast on the ground in each of the 40 plots; all the litter contained within the area covered by the metallic sheet was collected and oven dried at $65{ }^{\circ} \mathrm{C}$ to constant weight. Results are expressed in $\mathrm{Mg} \mathrm{ha}^{-1}$.

\section{Leaf decomposition}

Leaf decomposition rate was verified by means of the confinement of freshly fallen leaves into litter bags $(20 \mathrm{~cm} \times 20 \mathrm{~cm})$ made of $2 \mathrm{~mm}$ nylon mesh. Each litter bag was filled with $21.00 \mathrm{~g}$ of leaf material and placed on the ground in each of the 40 plots for monthly redemption during the year of study.

Leaf decay was calculated as a function of mean biomass losses over time by the following equation: remaining mass $(\%)=($ final mass/initial mass $) \times 100$. The constant $k$, calculated for $30,60,120,240$ and 360 days after the start of the experiment (5 periods) and also monthly (12 periods), was obtained through the simple exponential equation proposed by Olson (1963); where $\mathrm{X}_{\mathrm{t}}=\mathrm{X}_{0} \cdot \mathrm{e}^{\mathrm{kt}},\left(\mathrm{X}_{\mathrm{t}}=\right.$ dry weight of material remaining after $t$ days and $\mathrm{X}_{0}=$ dry weight of material at $\mathrm{t}=0)$. Half-life time was calculated by means of the equation $\mathrm{t}^{1 / 2}=\ln (2) / k($ OLSON, 1963).

\section{Data analysis}

Monthly data on litterfall, litter layer and leaf decomposition were compared by analysis of variance, followed by Tukey's test to identify significant differences between monthly means. Residual normality and homogeneity of variances were verified by the Shapiro-Wilk and Levene tests, respectively. When these assumptions were not met, the Kruskal Wallis non-parametric test was used. Analyses were carried out using the PAST program 2.15 (HAMMER et al., 2001).

\section{RESULTS}

\section{Litterfall}

Total litterfall was $4.70 \mathrm{Mg} \mathrm{ha}^{-1}$ over the study period, during which, October was the month with the highest proction, although not statistically different from contributions in April, May or June. In contrast, December was the month with the lowest litterfall production, with an estimate similar to those found in January and August (Table 2). Except for November, the leaf fraction was the one that contributed most to total litterfall, with contributions above 50\% from March (Table 2 and Figure 2).

The branches represented the second largest contribution to total litterfall production, followed by miscellaneous residues and last, reproductive parts. However, this pattern was not constant for 
Table 2. Total litterfall ( $\mathrm{Mg} \mathrm{ha}^{-1}$ ) and fractions $\left(\mathrm{kg} \mathrm{ha}^{-1}\right)$ in Eucalypt stand at Água Limpa Farm, Distrito Federal.

Tabela 2. Produção total de Serapilheira $\left(\mathrm{Mg} \mathrm{ha}^{-1}\right)$ e frações $\left(\mathrm{kg} \mathrm{ha}^{-1}\right)$ em povoamento de eucalipto, na Fazenda Água Limpa, Distrito Federal.

\begin{tabular}{cccrrr}
\hline Months & Leaves & $\begin{array}{c}\text { Reproductive } \\
\text { parts }\end{array}$ & Branches & Miscellaneous & Total \\
\hline N & $43.7(11.9 \%)$ & $27.6(7.5 \%)$ & $176.1(47.9 \%)$ & $120.1(32.7 \%)$ & $0.3675 \mathrm{c}(100 \%)$ \\
D & $54.2(39.5 \%)$ & $10.5(7.7 \%)$ & $38.8(28.2 \%)$ & $33.7(24.5 \%)$ & $0.1372 \mathrm{~d}(100 \%)$ \\
J & $76.4(47.3 \%)$ & $10.5(6.5 \%)$ & $42.5(26.3 \%)$ & $32.1(19.9 \%)$ & $0.1614 \mathrm{~d}(100 \%)$ \\
F & $143.1(37.1 \%)$ & $10.6(2.8 \%)$ & $151.0(39.1 \%)$ & $81.1(21.0 \%)$ & $0.3858 \mathrm{bc}(100 \%)$ \\
M & $110.0(78.8 \%)$ & $5.0(3.6 \%)$ & $5.2(3.7 \%)$ & $19.4(13.9 \%)$ & $0.1396 \mathrm{~d}(100 \%)$ \\
A & $549.9(97.9 \%)$ & $6.2(1.1 \%)$ & $5.8(1.0 \%)$ & $16.4(2.9 \%)$ & $0.5619 \mathrm{a}(100 \%)$ \\
M & $677.1(94.9 \%)$ & $5.9(0.8 \%)$ & $19.9(2.8 \%)$ & $10.9(1.5 \%)$ & $0.7138 \mathrm{a}(100 \%)$ \\
J & $591.8(93.7 \%)$ & $11.9(1.9 \%)$ & $12.5(2.0 \%)$ & $15.4(2.4 \%)$ & $0.6316 \mathrm{a}(100 \%)$ \\
J & $276.3(82.7 \%)$ & $30.7(9.2 \%)$ & $8.9(2.7 \%)$ & $18.1(5.4 \%)$ & $0.3339 \mathrm{bc}(100 \%)$ \\
A & $157.9(64.3 \%)$ & $17.5(7.1 \%)$ & $35.2(14.3 \%)$ & $35.0(14.2 \%)$ & $0.2455 \mathrm{bcd}(100 \%)$ \\
S & $299.4(94.7 \%)$ & $8.5(2.7 \%)$ & $8.4(2.6 \%)$ & $40.2(12.7 \%)$ & $0.3163 \mathrm{bc}(100 \%)$ \\
O & $712.1(91.6 \%)$ & $8.4(1.1 \%)$ & $33.1(4.3 \%)$ & $23.8(3.1 \%)$ & $0.7774 \mathrm{a}(100 \%)$ \\
Total & $\mathbf{3 . 6 9 1 . 9 ( 7 7 \% )}$ & $\mathbf{1 5 3 . 2 ( 3 \% )}$ & $\mathbf{5 3 7 . 2 ( 1 1 \% )}$ & $\mathbf{4 4 6 . 1 ( 9 \% )}$ & $\mathbf{4 . 7 0}(\mathbf{1 0 0} \%)$ \\
\hline
\end{tabular}

Means followed by the same lower case on the column do not differ by Tukey test at $5 \%$ probability.

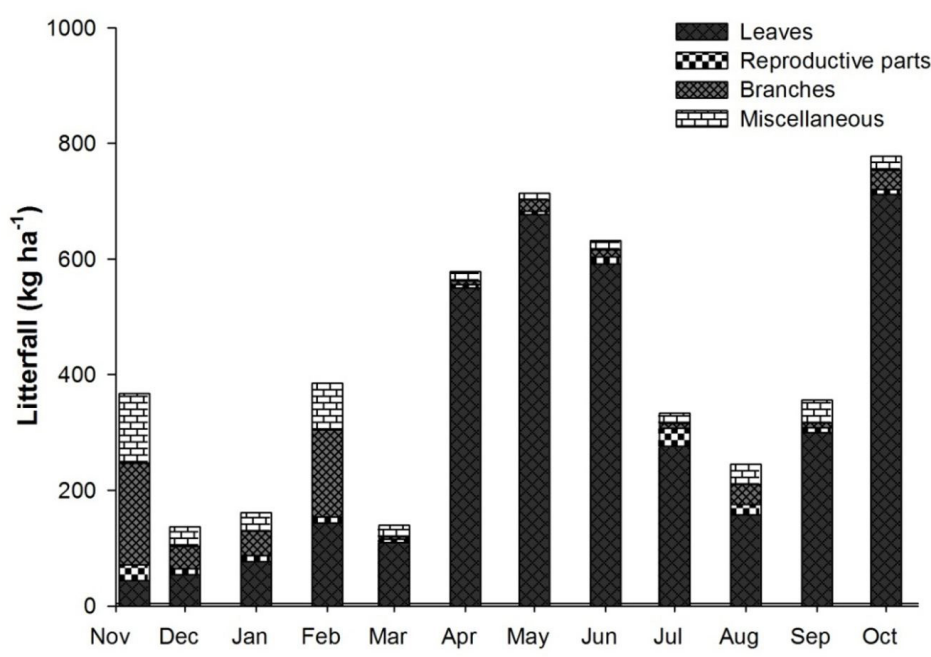

Figure 2. Litterfall fractions ( $\mathrm{kg} \mathrm{ha}^{-1}$ ) in a Eucalypt stand at Água Limpa Farm, Distrito Federal.

Figura 2. Frações de serapilheira $\left(\mathrm{kg} \mathrm{ha}^{-1}\right)$ em plantio de eucalipto, na Fazenda Água Limpa, Distrito Federal.

all months of the year, e.g., in November/2015 and February/2016 branches contributed to litterfall more than leaves did (Table 2 and Figure 2). In July, reproductive parts contributed $9.2 \%$ of litterfall production, higher percentage than that was observed for branches and miscellaneous residues.

\section{Litter layer}

Average accumulation of litter layer over the study period was $14.88 \mathrm{Mg} \mathrm{ha}^{-1}$. October and September showed the highest estimates (Table 3). Thus, as occurred with the litterfall, the end of the dry period and the beginning of the rainy season were the spans of higher contribution to the litter layer accumulation. The month with the lowest layer formation was June, although not differing significantly from December or January.

\section{Leaf decomposition}

When using all periods, monthly exponential regression litter bags retrieved a more pronounced curve showed by the exponential regression (Figure 3B), compared to the decay in only five periods (Figure 3A). This difference can also be attested in the values of constant $k$, which was 0.0009 for the five periods and 0.0008 for 12 periods (Table 4).

Although it may seem a small difference, this distinction represents almost 100 days less when using the standard litter bags redemption time, which is five periods (Table 4). This causes overestimation of decay measurements, compared to what is observed when the $k$ constant value is obtained 
Valadão et al. - Litterfall, litter layer and leaf decomposition in Eucalyptus

stands on Cerrado soils

Table 3. Mean and standard deviation of litter layer $\left(\mathrm{Mg} \mathrm{ha}^{-1}\right)$ in Eucalypt stands at Água Limpa Farm, Distrito Federal.

Tabela 3. Média e desvio padrão da camada de serapilheira ( $\mathrm{Mg} \mathrm{ha}^{-1}$ ) em povoamento de eucalipto, na Fazenda Água Limpa, Distrito Federal.

\begin{tabular}{cc}
\hline Months & Litter layer \\
\hline $\mathbf{N}$ & 11.89 degi $( \pm 2.21)$ \\
$\mathbf{D}$ & $13.65 \mathrm{chi}( \pm 3.64)$ \\
$\mathbf{J}$ & 12.38 defgh $( \pm 2.42)$ \\
$\mathbf{M}$ & $13.71 \mathrm{cg}( \pm 3.28)$ \\
$\mathbf{A}$ & 16.31 bef $( \pm 3.39)$ \\
$\mathbf{M}$ & $14.56 \mathrm{cf}( \pm 3.41)$ \\
$\mathbf{J}$ & $14.17 \mathrm{ce}( \pm 3.07)$ \\
$\mathbf{J}$ & $10.74 \mathrm{~d}( \pm 2.10)$ \\
$\mathbf{A}$ & $15.27 \mathrm{bc}( \pm 3.71)$ \\
$\mathbf{S}$ & $17.83 \mathrm{ab}( \pm 5.29)$ \\
$\mathbf{O}$ & $19.03 \mathrm{a}( \pm 4.34)$ \\
& $19.03 \mathrm{a}( \pm 4.35)$ \\
Mean & $\mathbf{F ~ ( 1 1 , ~ 4 6 8 ) = 2 3 . 8 1 , ~ p < 0 . 0 1 ~}$ \\
\hline
\end{tabular}

Means followed by the same lower case on the column do not differ by Tukey test at $5 \%$ probability.

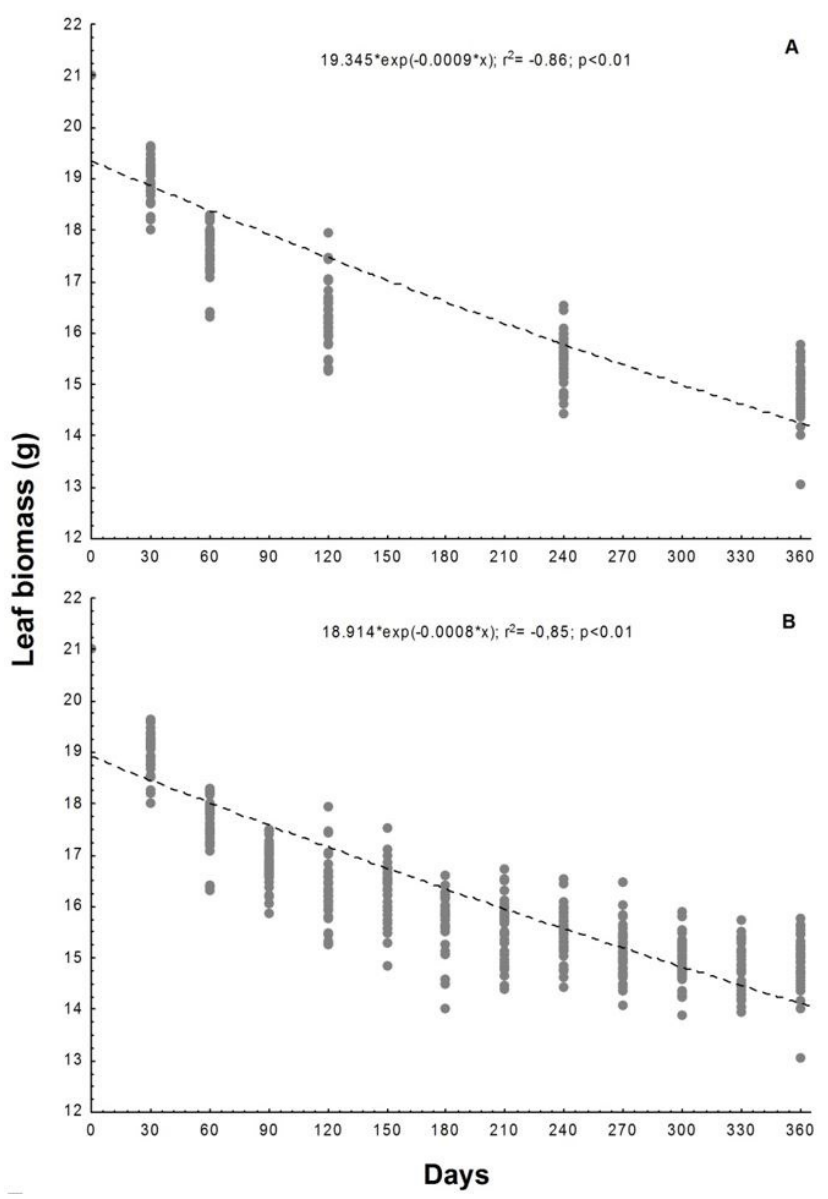

Figure 3. Exponential regression of leaf biomass decay ( $g$ ) over 5 (A) and 12 (B) periods in a Eucalypt stand at Água Limpa Farm, Distrito Federal.

Figura 3. Regressão exponencial de decaimento de biomassa foliar ( $\mathrm{g}$ ) ao longo de 5 ( $\mathrm{A}$ ) e 12 (B) períodos em plantio de eucalipto, na Fazenda Água Limpa, Distrito Federal.

through collections every month of the year. In one year, the total estimate of leaf decomposition was $1.70 \mathrm{Mg} \mathrm{ha}^{-1}$ (Table 4).

When comparing all the periods of decay of leaf biomass, it was possible to verify a difference in relation to the initial mass, in the zero time, only at 90 days after the beginning of experiment. At 360 days -last collection- the remaining material was $14.88 \mathrm{~g}$, but this average did not differ from 210, 240270,300 and 330 days (Table 5). We verified that in one year, less than $50 \%$ of the leaf biomass contained in litter bags was decomposed. 
Table 4. Parameters obtained by means of exponential regression for leaf decomposition, using 5 or 12 periods in a Eucalypt stand at Água Limpa Farm, Distrito Federal.

Tabela 4. Parâmetros obtidos por meio da regressão exponencial para decomposição foliar, utilizando 5 e 12 períodos em povoamento de eucalipto, na Fazenda Água Limpa, Distrito Federal.

\begin{tabular}{ccc}
\hline & $\mathbf{5}$ periods & 12 periods \\
\hline Equation & $\mathrm{X}_{\mathrm{t}}=19.345^{\star} \mathrm{e}^{-0.0009}$ & $\mathrm{X}_{\mathrm{t}}=18.914^{*} \mathrm{e}^{-0.0008}$ \\
$\boldsymbol{k}$ & 0.0009 & 0.0008 \\
$\mathrm{~T}^{1 / 2}$ (days) & 770 & 866 \\
Decomposed biomass $\left(\mathbf{M g ~ h a}^{-1}\right)$ & 1.70 & 1.70 \\
\hline
\end{tabular}

Table 5. Average weight $(\mathrm{g})$ and percentage of leaf biomass remaining during twelve periods in a Eucalypt stand, at Água Limpa Farm, Distrito Federal.

Tabela 5. Peso médio $(\mathrm{g}$ ) e porcentagem de biomassa foliar remanescente ao longo de doze períodos em povoamento de eucalipto, na Fazenda Água Limpa, Distrito Federal.

\begin{tabular}{cc}
\hline Days after the beginning of experiment & Remaining leaf biomass \\
\hline 30 & $21.00 \mathrm{a}(100 \%)$ \\
60 & $19.01 \mathrm{ab}(87.8 \%)$ \\
90 & $17.61 \mathrm{ac}(81.3 \%)$ \\
120 & $16.85 \mathrm{bc}(77.8 \%)$ \\
150 & $16.31 \mathrm{~cd}(75.3 \%)$ \\
180 & $16.27 \mathrm{ce}(75.2 \%)$ \\
210 & $15.78 \mathrm{def}(72.9 \%)$ \\
240 & $15.53 \mathrm{deg}(71.7 \%)$ \\
300 & $15.47 \mathrm{fg}(71.5 \%)$ \\
330 & $15.16 \mathrm{fg}(70.0 \%)$ \\
360 & $14.96 \mathrm{~g}(69.1 \%)$ \\
& $14.84 \mathrm{~g}(68.5 \%)$ \\
& $14.88 \mathrm{~g}(68.7 \%)$ \\
\hline
\end{tabular}

Means followed by the same lower case on the column do not differ.

\section{DISCUSSION}

\section{Litterfall}

Total litterfall values observed in this study agree well with those obtained in more recent stand in south and southeast regions of the country. In a stand of E. dunnii planted in spacing $2.0 \times 3.5 \mathrm{~m}$ and at 16.5 months of age in Alegrete - RS, Corrêa et al. (2013) estimated 4.1 Mg ha ${ }^{-1}$. Similarly, in the Sesmarias river basin, which includes the states of São Paulo and Rio de Janeiro, the production was 4.4 $\mathrm{Mg} \mathrm{ha}^{-1}$ in a planting of hybrids E. urophylla and E. grandis with $3 \times 2 \mathrm{~m}$ spacing and at 24 month of age (MELOS et al., 2010). Even in a crop-livestock-forest integrated system, in which corn was the crop component, Freitas et al. (2013) estimated the production of litterfall in $4.2 \mathrm{Mg} \mathrm{ha}^{-1}$ in an E. grandis $\mathrm{x}$ E. urophylla hybrid planting in the state of Minas Gerais, thus, demonstrating the viability of the hybrid to produce litterfall even in different planting sites and arrangements.

It should be emphasized that no acidity correction was made for the planting of the present study. Nevertheless, litterfall has not been affected over time. In addition to decreasing the action of exchangeable $\mathrm{H}^{+}$and $\mathrm{Al}^{+}$ions, liming raises $\mathrm{Ca}^{2+}$ and $\mathrm{Mg}^{2+}$ content in dystrophic soils, which are characteristically highly acidic. In so doing, liming provides elements which are highly demanded by Eucalypt. Another factor that may explain regular production of litterfall is biogeochemical cycling. Older plantings become more dependent on the litter deposited on the ground and its decomposition and release of nutrients to the soil (SCHUMACHER; VIEIRA, 2015).

The end of the drought, between September and October, was the period of greatest litterfall production. This factor may be related to the climatic conditions that predominate in the region in this period, dominated by low soil water content and, consequently, greater foliar abscission as it occurs in other species present in the biome (CIANCIARUSO et al. 2006; GIÁCOMO et al. 2012; SILVA et al. 2007). The lowest estimate of litterfall, which occurred in December/2015, is attributed to the beginning of the rainy season, in which the soil more effectively resumes its hydric capacity to provide the roots. 
Valadão et al. - Litterfall, litter layer and leaf decomposition in Eucalyptus

stands on Cerrado soils

\section{Litter layer}

As observed for the estimation of litterfall contribution, the litter layer accumulated on the ground also presented higher average values in the month of October. This similarity may be related to inherent characteristics of dystrophic and alic soils. Under these conditions, microbial activity which may contribute up to half of the potential for soil nitrogen mineralization in Eucalypt plantations, tends to be lower (BARRETO et al., 2012; SOUSA et al., 2007).

In the soil condition before mentioned, litter layer estimates were higher than those reported by other studies conducted on hybrid E. grandis x E. urophylla plantations on Latosol (Oxisols) in the Cerrado (GATTO et al., 2014; LIMA et al., 2015a). The fact of being an unmanaged planting, aged 60 months and, can also be associated with this finding. In older stands, degradation of the contributed material tends to occur to a lesser extent, therefore indicating a slower decomposition (NOUVELLON et al., 2012).

\section{Leaf decomposition}

The percentage of remaining biomass in the litter bags still not decomposed was similar to that found in an E. urophylla plantation in the state of Bahia, in which Pinto et al. (2016) verified rates of $73.56 \%$ at 180 days after the beginning of the experiment. In the state of São Paulo, Bachega et al. (2016) at 180 days after experiment initiation, it was $63.00 \%$ of the leaf biomass remaining in the litter bags in an E. grandis planting. This pattern of recalcitrance seems to be characteristic of eucalypt leaves and may be mainly due to the high levels of lignin and polyphenols present.

Lignin and polyphenols are structural constituents of organic compounds that persist in the Eucalypt leaves. In the present study, leaf biomass decay was evidenced only after 90 days from experiment initiation. Pinto et al. (2016) reported that sugar content was the first to be decomposed over the first three months after leaves fell on the ground; however, lignin content tends to remain constant over a much longer period of time (COSTA et al., 2005). After the first quarter, most of the strongest structures rich in lignin, cellulose, waxes and tannins, such as ribs and petioles, still remain, reducing the rate of decomposition (CARVALHO et al., 2009; LIMA et al., 2015b ; VIERA et al., 2014b).

Lignin, which is associated to the low palatability of organic plant residues for edaphic fauna (GAMA-RODRIGUES et al., 2003), contributes to the low value of the $k$ rate of decomposition. In a planting of E. grandis $\mathrm{x}$ E. urophylla, in the state of Minas Gerais, Cunha Neto et al. (2013), obtained a $k$ value of 0.0028 with a half-life of 247 days. Despite being a similar hybrid, inherent characteristics of the site may have influenced the low value of the constant in the present study.

Proposed by Olson (1963), rate $k$, obtained through exponential regression, is still one of the most didactic and safe methods to estimate the decomposition rate, usually of leaves, in forest environments. According to Scoriza et al. (2012) the confinement of leaves in litter bags provides a visual perception of material decay over time through the regression curve. However, by choosing to redeem in five periods, which is the usual practice, regression models may overestimate the $k$ value. Indeed, in comparison to a model composed of 12 rescues, the difference in half-life was almost 100 days longer than when only five rescues are considered. This indicates that the assimilation capacity of precipitated organic matter in the soil, under Eucalypt stands, may be even lower.

\section{CONCLUSION}

The results obtained by sampling litterfall, litter layer and leaf decomposition in an Eucalypt stand showed high production of plant residues; however, the decomposition of this material in the soil was shown to be quite slow. This can be attributed mainly to the inherent of edaphoclimatic characteristics as well as to the characteristics of the plant residues. Although admittedly highly recalcitrant, litter from the Eucalypt stand can be an alternative for the preservation of the physical properties of the soil, particularly its hydric retention capacity. The use of a greater number of collection periods for determining the exponential regression of constant $k$ is important in order not to overestimate the time of disappearance of the remaining biomass. 


\section{ACKNOWLEDGMENTS}

We gratefully acknowledge all friends from Fazenda Água Limpa, especially Sebastião Carlos Abadio, Geraldo Cardoso Oliveira, Augusto Pereira Alves, Mauro Barbosa dos Santos, Luiz Carlos Oliveira, Weiner Raulã Moreira Diniz and Augusto Álvaro Pereira dos Santos.

\section{REFERENCES}

ALVARES, C. A.; STAPE, J. L.; SENTELHAS, P. C.; GONÇALVES, J. L. M.; SPAROVEK, G. Köppen's climate classification map for Brazil. Meteorologische Zeitschrift, Stuttgard, v. 22, n. 6, p. 711-728, 2014.

ASSIS, P. C. R.; STONE, L. F.; MEDEIROS, J. C.; MADARI, B. E.; OLIVEIRA, J. M.; WRUCK, F. J. Atributos físicos do solo em sistemas de integração lavoura-pecuária-floresta. Revista Brasileira de Engenharia Agrícola e Ambiental, Campina Grande, v. 19, n. 4, p. 309-316, 2015.

BACHEGA, L. R.; BOUILLET, J. P.; CÁSSIA, P. M.; SAINT-ANDRÉ, L.; BOUVET, J. M.; NOUVELLON, Y.; GONÇAÇVES, J. L. M.; AGNÈS, R.; LACLAU, J. P. Decomposition of Eucalyptus grandis and Acacia mangium leaves and fine roots in tropical conditions did not meet the Home Field Advantage hypothesis. Forest Ecology and Management, Amsterdam, v. 359, p. 33-43, 2016.

BARRETO, P. A. B.; GAMA-RODRIGUES, A. C.; GAMA-RODRIGUES, E. F.; BARROS, N. F. Nitrogen balance in soil under eucalyptus plantations. Revista Brasileira de Ciência do Solo, Viçosa, v. 36, p. 1239-1248, 2012.

CARVALHO, W.; CANILHA, L.; FERRAZ, A.; MILAGRES, A. M. F. Uma visão sobre a estrutura, composição e biodegradação da madeira. Química Nova, São Paulo, v. 32, n. 8, p. 2191-2195, 2009.

CIANCIARUSO, M. V.; PIRES, J. S. R.; DELITTI, W. B. C.; SILVA, E. F. L. P. Produção de serapilheira e decomposição do material foliar em um cerradão na Estação Ecológica de Jataí, município de Luiz Antônio, SP, Brasil. Acta Botanica Brasilica, São Paulo, v. 20, p. 49-59, 2006.

CORRÊA, R. S.; SCHUMACHER, M. V.; MOMOLLI, D. R. Deposição de serapilheira e macronutrientes em povoamento de Eucalyptus dunnii Maiden sobre pastagem natural degradada no Bioma Pampa. Scientia Forestalis, Piracicaba, v. 41, p. 65-74, 2013.

COSTA, G. S.; GAMA-RODRIGUES, A. C.; CUNHA, G. M. Decomposição e liberação de nutrientes da serapilheira foliar em povoamentos de Eucalyptus grandis no Norte Fluminense. Revista Árvore, Viçosa, v. 29, n. 4, p. 563$570,2005$.

CUNHA NETO, F. V.; LELES, P. S. S.; PEREIRA, M. G.; BELLUMATH, V. G. H.; ALONSO, J. M. Acúmulo e decomposição da serapilheira em quatro formações florestais. Ciência Florestal, Santa Maria, v. 23, n. 3, p. 379-387, 2013.

FARINACI, J. S.; FERREIRA, L. C.; BATISTELLA, M. Transição florestal e modernização ecológica: a eucaliptocultura para além do bem e do mal. Ambiente e Sociedade, São Paulo, v. 16, p. 25-46, 2013.

FINOTTI, R.; FREITAS, S. R.; CERQUEIRA, R.; VIEIRA, M. V. A method to determine the minimum number of litter traps in litterfall studies. Biotropica, Hoboken, v. 35, n.3, p. 419-421, 2003.

FREITAS, E. C. S.; OLIVEIRA NETO, S. N.; FONSECA, D. M.; SANTOS, M. V.; LEITE, H. G.; MACHADO, V. D. Deposição de serapilheira e de nutrientes no solo em Sistema Agrossilvipastoril com eucalipto e acácia. Revista Árvore, Viçosa, v. 37, p. 409-417, 2013.

GAMA-RODRIGUES, A. C.; BARROS, N. F.; SANTOS, M. L. Decomposição e liberação de nutrientes do folhedo de espécies florestais nativas em plantios puros e mistos no sudeste da Bahia. Revista Brasileira de Ciência do Solo, v. 27, p. 1021-1031, 2003.

GATTO, A.; BUSSINGUER, A. P.; RIBEIRO, F. C.; AZEVEDO, G. B.; BUENO, C. B.; MONTEIRO, M. M.; SOUZA, P. F. Ciclagem e Balanço de Nutrientes no Sistema Solo-Planta em um Plantio de Eucalyptus sp., no Distrito Federal. Revista Brasileira de Ciência do Solo, Viçosa, v. 38, p. 879-887, 2014.

GIÁCOMO, R. G.; PEREIRA, M. G.; MACHADO, D. L. Aporte e decomposição de serapilheira em áreas de cerradão e mata mesofítica na estação ecológica de Pirapitinga-MG. Ciência Florestal, Santa Maria, v. 22, p. 669-680, 2012.

GIÁCOMO, R. G.; ALVES, M. C.; CAMARA, R.; PEREIRA, M.; GERVASIO; A.; OTTON, G.; SOUTO, S. N.; MORAES, M. L. T. Litterfall and Nutrient Input in a Degraded Area. Floresta e Ambiente, Seropédica, v. 24, p. 1-9, 2017.

Sci. For., Piracicaba, v. 47, n. 122, p. 256-264, jun. 2019 DOI: doi.org/10.18671/scifor.v47n122.08 
Valadão et al. - Litterfall, litter layer and leaf decomposition in Eucalyptus

stands on Cerrado soils

HAMMER, O.; HARPER, D. A. T.; RYAN, P. D. PAST: Paleontological statistics software package for education and data analysis. Palaeontologia Electronica, Oslo, v. 4, n. 1, p. 1-9, 2001.

LAUBER, C.; KNIGHT, R.; HAMADY, M.; FIERER, N. Soil pH as apredictor of soil bacterial community structure at the continentalscale: a pyrosequencing-based assessment. Applied and Environmental Microbiology, Washington, v. 75, p. 5111-5120, 2009.

LIMA, N. L.; MELO-SILVA, C.; CALIL, F. N.; SOUZA, K. R.; MORAES, D. C. Acúmulo de serapilheira em quatro tipos de vegetação no estado de Goiás. Enciclopédia Biosfera, Goiânia, v. 11, p. 39-46, $2015 a$.

LIMA, R. P.; FERNANDES, M. M.; FERNANDES, M. R. M.; MATRICARDI, E. A. T. Aporte e Decomposição da Serapilheira na Caatinga no Sul do Piauí. Floresta e Ambiente, Seropédica, v. 22, p. 42-49, 2015 b.

MElOS, A. R.; SATO, A. M.; COELHO NETTO, A. L. Produção, Estoque e Retenção Hídrica da Serrapilheira em Encosta Sob Plantio de híbridos de Eucalyptus urophylla e Eucalyptus grandis: Médio Vale do Rio Paraíba do Sul. Anuário do Instituto de Geociências, Rio de Janeiro, v. 2, p. 66-73, 2010.

MIRANDA, C. C.; CANELLAS, L. P.; NASCIMENTO, M. T. Caracterização da matéria orgânica do solo em fragmentos de mata atlântica e em plantios abandonados de eucalipto. Revista Brasileira de Ciência do Solo, Viçosa, v. 31, n. 5, p. 905-916, 2007.

NOUVELLON, Y. P.; EPRON, D.; MARSDEN, C.; KINANA, A.; MAIRE, G.; DELEPORTE, P.; SAINT-ANDRÉ, L.; BOUILLET, J. P.; LACLAU, J. P. Age-related changes in litter inputs explain annual trends in soil CO2 effluxes over a full Eucalyptus rotation after afforestation of a tropical savannah. Biogeochemistry, Dordrecht, v. 111, p. 515-533, 2012

OLSON, J. S. Energy storage and the balance of producers and decomposers in ecological systems. Ecology, Hoboken, v. 44, n. 2, p. 322-331, 1963.

PINTO, H. C. A.; BARRETO, P. A. B.; GAMA-RODRIGUES, E. F.; OLIVEIRA, F. G. R. B.; PAULA, A.; AMARAL, A. R. Decomposição da serapilheira foliar de floresta nativa e plantios de Pterogyne nitens e Eucalyptus urophylla no sudoeste da Bahia. Ciência Florestal, Santa Maria, v. 26, p. 1141-1153, 2016.

SCHUMACHER, M. V.; VIERA, M. Ciclagem de nutrientes em plantações de eucalipto. In: SCHUMACHER, M. V.; VIERA, M. (Org.). Silvicultura do Eucalipto no Brasil. Santa Maria: UFSM, 2015, p. 273-307.

SCORIZA, R. N.; PEREIRA, M. G.; PEREIRA, G. H. A.; MACHADO, D. L.; SILVA, E. M. R. Métodos para coleta e análise de serrapilheira aplicados à ciclagem de nutrientes. Floresta e Ambiente, Rio de Janeiro, v. 2, n. 2, p. $1-18,2012$.

SILVA, C. J.; SANCHES, L.; BLEICH, M. E.; LOBO, F. A.; NOGUEIRA, J. S. Produção de serrapilheira no Cerrado e Floresta de Transição Amazônia-Cerrado do Centro-Oeste Brasileiro. Acta Amazonica, Manaus, v. 37, 543-548, 2007.

SOUSA, D. M. G.; LOBATO, E. Adubação com nitrogênio. In: SOUSA, D. M. G.; LOBATO, E. (Ed.). Cerrado: correção do solo e adubação. Planaltina: Embrapa Cerrados, 2004. p. 129-144.

SOUSA, D. M. G.; MIRANDA, L. N.; OLIVEIRA, S. A. Acidez do solo e sua correção. In: NOVAIS, R. F.; ALVAREZ, V. H. A.; BARROS, N. F.; FONTES, R. L. F. F.; CANTARUTTI, B. R.; NEVES, J. C. L. (Org.). Fertilidade do Solo. Viçosa: Sociedade Brasileira de Ciência do Solo, 2007, p. 205-274.

SUZUKI, L. E. A. S.; LIMA, C. L. R.; REINERT, D. J.; REICHERT, J. M.; PILLON, C. N. Estrutura e armazenamento de água em um Argissolo sob pastagem cultivada, floresta nativa e povoamento de eucalipto no Rio Grande do Sul. Revista Brasileira Ciência do Solo, Viçosa, v. 38, p. 94-106, 2014.

VIERA, M.; SCHUMACHER, M. V.; ARAÚJO, E. F.; CORRÊA, R. S.; CALDEIRA, M. V. W. Deposição de serapilheira e nutrientes em plantio de Eucalyptus urophylla x E. globulus. Floresta e Ambiente, Seropédica, v. 21, n. 3, p. 327$338,2014 a$.

VIERA, M.; SCHUMACHER, M. V.; ARAÚJO, E. F. Disponibilização de nutrientes via decomposição da serapilheira foliar em um plantio de Eucalyptus urophylla x Eucalyptus globulus. Floresta e Ambiente, Seropédica, v.21, p.307$315,2014 b$.

Received: $11 / 09 / 2017$

Accepted: 09/21/2018 